\title{
The soteriological importance of the hypostatic union*
}

\author{
Phd. candidate, Constantin-Valentin BUGIULESCU \\ Faculty of Orthodox Theology, University of Bucuresti, \\ ROMANIA \\ E-mail: bugiulescu_constantin@yahoo.com
}

\begin{abstract}
This article deals with the dogma of the union of the two natures, divine and human, in Christ's pre-existing Hypostasis and the redeeming importance of this union for man's deification as full realization in Christ. Christ, the preexisting Hypostasis, becomes by oikonomia a hypostasis uniting in Himself in an undivided and unseparated, unmixed and unchanged way - two different principles, two natures united in a special way, we could even say a completely special way. This new way of union and living makes the fallen human nature be lifted by the oikonomia of love to the state of partner of the Father, oikonomia realized by and in Christ's community of hypostasis. Christ is the One Who gives everything back to the human nature in order for it to be accomplished, but, moreover, He realizes in Himself the accomplishment of all the potentials and virtualities that used to constitute the human nature and which, because of sin and implicitly the deepening in it (the fall), decreased in intensity so that they no longer had the power to generate the good existence that comes and is directed through the creation towards God. Christ's embodiment - as a completely special way of assuming the human nature - generates, on the one hand, the re-establishment of the fallen nature and, on the other hand, by the assuming, by Christ, of all the things pertaining to the nature, except for sin, and His descent on their level of existence and power of development, our deification is mysteriously realized, as well. It is by the embodiment that Christ "becomes a man for men but also of men", born as a man of the Virgin Mary and of the Holy Spirit, "for us, men, and our salvation".
\end{abstract}

Keywords: Logos, assuming, human nature (humanity), hypostasis, perichoresis, kenosis, hypostatizing, enhypostatizing, deification.

\section{INTRODUCTION}

Man's deification represents the process of personal completion and ascent of man to the state of "son" of God. Even by creation man tends to ascend, through love for God, "by love for the uncharitable love, up to the point where he receives the hypostatization or personalization of his nature in the Word" [1]. All the divine oikonomia, from the creation and up to the embodiment of God's Son, pursues this personalization of the humanity that will become complete in the future life. This personalization, as Father Dumitru Stăniloae says, "is founded on the humanization of God's Son and results, on the other hand, in our deification, which relies on the deification of the human nature assumed by Christ" [2].

The Son's embodiment and our community of nature with Him produces in us this personalization or full realization of everyone in Him as well as the hypostatization of all of 
us by Him. This union of everyone realized in Him is the product of the hypostatic union of the two natures of the Hypostas of Christ. The unity of the divine-human person is the factor of direct union of the creative divine Logos with the people and the creation, based on the relation we have with our fellows and the human nature present in Christ along with His divine nature. In Him, Father Stăniloae says, "we see and realize the human nature fully transparent for God and the divine nature fully given to us" [3].

Jesus Christ's embodiment represents the maximum capitalization of the human nature before God, Who created it to deify it and not to lose it. The embodiment is, therefore, as Saint Maximus the Confessor says, the illustration in the body "of the image of the living of a divine form [of life], which gives us the hope of resurrection and eternal life" [4].

\section{The mystery of the Embodiment or God's love for the people}

The embodiment of the Son makes God's work directed to the people much more efficient, it is the passage from the work of relation, realized before the embodiment, to God's personal and direct work of deification and transfiguration of the world. By the embodiment, God's Son Himself became maximally united with the human nature, producing the maximal advancement of God to us. Father Dumitru Stăniloae speaks about the highest and full realization of God's and man's union in Christ. In Christ, says Father Stăniloae, "the maximum unity is realized, He is the One Who fulfils and unites the divine will of unification with us to the human thirst of union with everybody in the divine centre unifying everyone". The un-confounded and hypostatic unification of the natures in Christ realizes on the one hand the resettlement of man in harmony with the divine will, "who wishes and thinks fully rationally the good of all in agreement and solidarity with everything", and on the other hand, what is fully realized is the union of God with the other people. Christ becomes, as Father Stăniloae says, "the man for men because, in Him, man is for God or the human nature opens itself fully to God" [5]. In Christ, one lives really, completely and directly the opening of the human nature towards boundlessness and infinity. This openness is the exclusive product of the divine nature towards those who participate and live the real hypostatic existence of the embodied Logos. In Christ, each hypostasis lives the accomplishment of his hypostasis, the boundlessness and the infinity, as a need springing from the persistent will to full achievement of one's own hypostasis. By this, Christ becomes Hypostasis of the hypostases or as Nicholas Cabasilas says, Christ is the "Head of the limbs" [6], in Him being realized the fulfilment of the human nature and of all the persons by the fact that the Logos becomes the direct Hypostasis of the human nature and the ultimate Hypostasis of the human persons.

Christ's Person, composed "of two natures" [7] expresses on the one hand the unconfounded union of the two natures in the One Hypostasis, and the impossibility of separating them in actu. The union of the natures in the Hypostasis Christ is the eternal act of deification of the human nature and humanization of the Word, is the eternal act of passage of God in the human mind and nature, as Saint Maximus the Confessor says. [8] This union actually produces as well the eternal closeness of the two partners, God and man.

The un-confoundedness of the natures in the hypostatic union of the Word, as well as the keeping in unity of the difference between the natures, makes it possible to know one nature through the prism of the other. Thus, God is known by the human nature based on the relation of union that it has with Him in the Hypostasis of Christ, but man also becomes the object of God's knowledge. This is about the mutual knowledge between man and God as an effect of the mutual interpenetration of the natures, whose support is the Hypostasis able to 
unite in an undivided and unseparated manner the two natures. This eternal hypostasis of the Word, beside the fact that it offers both of the natures the integrity of their specific way of being, at the same time, keeps them united in an uncomponded and unchanged manner. "All these actions are of One and the Same, although they come from different natures" [9] says Leontius of Byzantium. The divine nature lives the human things by the complete human nature present in Christ, just as the human nature lives the complete God present in the same unique Hypostasis. This is about a mutual communication of the features specific of each nature, relying on a dynamic perichoresis activated in both of the natures to the full in the pre-existing eternal Hypostasis of the Word. "This, says Saint John Damascene, is not a work of the nature, but a sort of oikonomic condescendence" [10]. It is the action of the hypostatic will present in the Hypostasis Christ, a will that is one and the same with the Trinitarian will, because "the ideas" (the wills), do not belong to the being but to the common will of the Trinity. This is the mysterious action of the divine love.

The community of nature with Christ leads to the transmission on us of the qualities of His deified nature. "The deified body, says Father Stăniloae, being received in the body of the other people, resurrects and deifies our bodies as well" [11]. The Person of God the Word as a person accepted freely totally explains the union of all the people, but also their deification. "To us, Christ is neither just a model for us to imitate, nor just a great legislator that we should listen to. He is neither just the simple cause of our justice, but is the very Life and Justice in us." [12]. The hypostatic union is the one that settles between us but also in us the life-giving spring. The hypostatic union, says Vladimir Lossky, makes Christ our Mediator to God. Christ is the "mediator reconciling people with God by the Cross by which He abolishes the enmity" [13].

Saint Gregory of Nazianzus sees the oikonomia of salvation as a skilful plan of God meant to turn the tables on the slyness of the evil spirit, consequently freeing mankind from the tyranny of death. "It was necessary", says the Saint, "for God to make Himself a man and die, in order for us to be able to live again... There is nothing like my salvation. A few drops of Blood reconstitute the whole universe." [14]. It is from Christ's human nature deified by the uncreated divine energies that we take the power to become deified. By His deified human nature we also receive these deifying energies springing from the divine being present in God as partner of the hypostatic union. Thus, the hypostatic union is completely hypostatizing. In Christ is realized our own union with God. Christ is the one who assumed and eternally assumes the human nature because "What is not assumed cannot be saved" [15].

The hypostatic union means, on the one hand, the assuming by Christ of a human nature of His own, and on the other hand also our possibility to be assumed in Christ's Hypostasis. Therefore, our nature, says Vladimir Lossky, is "made up as well of two elements, just like Christ: Christ's deified human nature and our nature or rather the deifying divine energy and our nature" [16]. As we can notice, our own nature becomes in a certain way a part of Christ's deified human nature extended towards the world as Church. The Church is actually Herself Christ's Body meant to be as well "the fullness of the One Who fills all things in every way" (Ephesians 1:23). The target of the Church is a precise one everyone's unity with Christ on the basis of the community of nature and grace established by the Holy Spirit in the Church by the Holy Mysteries. Because if Christ is "Head of the Church Who is His Body", the Holy Spirit is "the One Who fulfils everything in everyone". This unity is understood by Origen in the sense of a progressive unity of everyone with Christ that is realized in the Church, is "the mystical wedding", says Origen, of the human 
soul with the divine Logos allegorically described in the Song of Songs. [17] In the Church, Christ is lived both as man and as God. In the Church is lived the hypostatic but also hypostatizing union, the Hypostasis of the Embodied Logos being the link uniting all that had been separated. Thus, the One Hypostasis becomes a cosmic hypostasis recognized by everyone, both by the spiritual nature and by the rational nature.

The entire Christology of the Holy Fathers is the Christology of the Logos unifying everyone by reason and love. Because reason is the link uniting the things separated once, and a lack of reason means but disunion of all the things united, love being the great unifying force present in man. "Receiving grace as Christ's love", says Saint Maximus the Confessor, "people unite their nature with the nature assumed by Christ, consequently returning to the same redeeming and deifying reason and will" [18]. Saint Maximus the Confessor sees the salvation of the human nature as a cause of Christ's bodily birth. "God the One Born", says Saint Maximus, "made Himself fully man in order to be able to work our salvation by means of a body active by nature, animated by mind and reason" [19]. In everything He made Himself fully man, except for sin, sin being not a component that is part of the human nature, but being an addition, something extra and a residue of the nature fallen as a consequence of the resistance to God's love. Christ made Himself a man among men and one of the men, in relation with all the men and implicitly with the whole cosmos, considering the divine nature present in His hypostasis, reason of the coming into existence of the whole cosmos. In Christ, says Saint Maximus, "man made himself the image of God and God made himself the image of man" [20], love being the one that makes man a god and makes God be like and show Himself like a man. Consequently, "God descends in the world, makes Himself a man and man ascends towards divine fullness, makes himself a god" [21].

Therefore, the reason and motive of God's Son's Embodiment is our salvation and deification, whose bedrock is the Father's redeeming and deifying love for men, because "so much did God love the world, that He gave His only begotten Son" (John 3:16). For this reason, Saint Maximus sees the act of the Embodiment strictly related to deification, one being implied by the other. "The Mystery of the embodiment of the Logos", says Saint Maximus, comprises in Itself the sense of all the symbols and enigmas of the Scripture and also the hidden sense of the whole sensible and intelligible creation. But he who knows the Mystery of the Cross and of the Tomb, also knows the ontological reasons of all things. Finally, he who penetrates even further and is initiated in the Mystery of the Resurrection learns the reason why God created everything since the beginning." [22].

The embodiment is the "philanthropic" act designating and highlighting God's providence towards us, the people. Christ's work is an "oikonomia of the mystery hidden since eternity in God" (Ephesians 3:9), a decision since eternity that was accomplished in Christ because "the union", says Vladimir Lossky, "is the ultimate goal for which the world was created out of nothing" [23]. "It is not sin or the fallen nature that are the cause of the Lord's coming", says Maximus the Confessor. Sin means distancing from the union, sin is the one that breaks up, diversifies, and does not have the quality of uniting. The cause and the necessity of Christ's coming is Christ Himself, for Whom and by Whom everything was created (John 1: 3). "Adam", says Saint Maximus "had been given the aim of gathering in his being the various spheres of the cosmos to give them deification getting to the union with God. If these successive unions or "syntheses" that go beyond the natural separations are realized, however, finally by Christ, is because Adam did not listen to his calling. Christ is the One who realizes these things one after the other, according to the order given to the first Adam" [24]. In this sense, Christ is also called "the New Adam", as the One that 
accomplished the service to which man was called since his creation by Adam. Christ as a man is the first and the only one who was able to cover inversely the inseparable relation between nature-sin-death in the union of the different natures, by His Embodiment, ending with the victory over death, freeing mankind from the burden of sin sheltered in man by his own will, because "The last enemy to be destroyed is death." (1 Corinthians 15:26).

\section{The hypostatic union, model and way of our union with God}

The creation of the world represents a descent of God down to all the levels of understanding of the creation. This descent occurred in a certain succession but also all of a sudden. God was able to light at the same time both the spiritual and the material world by His embodiment. Saint Maxim the Confessor considers essential the act of descent of God to the human nature (kenosis) in order to lift and deify the human nature. This refers to the humanization of the Logos and the deification of man in the loving kenotic act of the hypostatic union. "Everyone's ascent in Christ", says Saint Maximus, is co-ascent of Christ with them." [25]. By this, Saint Maximus manages to closely unite the mystical union and the accomplishment of the of the whole cosmos by Christology. Consequently, man's ascension in God coincides with the ascent and the gathering together of the sensible and intelligent world in Christ and by Christ in God. Christ is "the Way, the Truth and the Life" (1 John 14:6). Breaking up from Christ, denying Him is nothing else but breaking up from life and from the truth. It is by Him that the ascent of the emotions, the deification of the weak, the accomplishment of what is ongoing are realized. [26] "Man's road of perfection", says Father Dumitru Stăniloae, is the road from the Christ descended to our level of now to the eschatological Christ that will show Himself in glory at the end of the centuries" [27].

In Christ is realized "the intimacy with God" but also "the union of love". In Christ, says Saint Maximus, "is given the proof of God's most perfect love for men". [28] He is the One that unites in Himself both the divine Hypostases and the human hypostases, in Him pre-existing the models of all as an extension of the Word in everything, a prolongation of God's presence in all of us.

The renewal of the human nature was realized in the Person of the Embodied Logos by its being assumed and taken into His Hypostasis. "The descent of the Word, says Saint Maximus the Confessor, is the ascent of the human nature". Here, assuming is in the sense of lifting the human to the quality of part of the divine person. This is why, in the case of Christ, "assuming" involves the pre-existence of he who assumes, this is what Saint Maximus shows by the words "He made Himself a man, not He was made a man". Christ's hypostasis, although compounded, is not compounded like the human hypostases, which are compounded by the fact that their components are of the same age, brought together involuntarily, supposing one another; His compounded Hypostasis is explicitly the work of His liberty. "The Word of God compounded Himself in an ineffable manner, by assuming, with the body, the way to compounding" [29], says Saint Maximus, or as Vladimir Lossky says, "His Hypostasis includes both natures; He remains One, yet becoming the other" [30]. To allow an understanding as clear as possible regarding the way the human nature is assumed and regarding its inclusion in the eternal Hypostasis of the Word, Saint Maximus uses the analogy of the iron reddened in the fire (red-hot iron), he says: "In each work of Christ, one can see two different works, as in the case of a red-hot sword, which cuts but also burns, cuts in its quality of sharpened iron and burns in its quality of fire." [31]. The two natures remain different after the union, because the union does not change the natures at all, 
yet they continue to remain are the same time united in a single hypostasis. Following this union, the natures will begin to experience an interpenetration $(\pi \varepsilon \rho 1 \chi \omega \rho \eta \sigma i \varsigma \varepsilon 1 \varsigma \alpha \lambda \lambda \eta \lambda \alpha \varsigma)$ similar to the perichoretic union between the persons of the Holy Trinity. This interpenetration of the natures in Christ produces the descent of the divine energies and their communication directly to the human being. Yet, this perichoresis, says Saint John Damascene, is unilateral: "it comes from the divinity and not from the human nature" [32]. Therefore Christ's human nature is a deified nature, being penetrated by the divine energies even since the moment of the Embodiment.

Christ lives man in His divine nature and lives God in his human nature being helped by His Hypostasis that preserves the distinction between natures supernaturally, but does not accept their division and separation. "We are amazed, says Saint Maximus the Confessor, seeing how the limited and the unlimited - realities rejecting one another and which cannot be mixed together - are found united in Him and show each other mutually one in the other. Because the unlimited gets limited ineffably, while the limited extends to the level of the infinite" [33]. Love is the one that makes Him - Who is unadaptable by nature - adaptable into our nature. Thus, between the two natures of Christ there is a perichoretic relation, yet not one imposed by any of the two natures as it happens with the relation between body and soul. "The soul and the body", says Saint Maximus, "are not counted in a man, they being united, and even when they are separated at death they are not counted, but they involve a reference of one to the other." [34]. By this, Saint Maximus makes a clarification regarding the fact that although there is just one Hypostasis of the Logos, Which is given one worship and honour, This Hypostasis is a hypostasis made up of two separate natures that are kept together in unity in an undivided and unseparated manner by Him.

To give a correct meaning to the Christological dogma, the Fathers of the Fourth Ecumenical Synod turned to apophatism in the case of the hypostatic union as well. The four negation adverbs: in an unmixed way ( $\alpha \sigma v \gamma \chi v \tau \omega \varsigma)$, in an unchanged way ( $\alpha \tau \rho \varepsilon \pi \tau \omega \varsigma)$, in an undivided way $(\alpha \delta 1 \alpha \imath \rho \varepsilon \tau \omega \varsigma)$, in an unseparated way ( $\alpha \chi \omega \rho ı \varsigma \tau \omega \varsigma)$ present Christ as the divine person that has in Him two principles distinct and united at the same time. The dogmatic definition of the Fourth Synod confesses the existence of the union of two natures in a single hypostasis, Jesus Christ, Hypostasis Who existed as a person previous to the embodiment: "One and the Same God, truly God and truly man, of rational soul and body, of the same being with the Father according to the divinity and of the same being with us according to the humanity, in everything like us, except for sin, before all ages born of the Father, according to the divinity, and in the latter days, born of the Virgin Mary, Theotokos, according to the humanity: known in two natures, in an unmixed, unchanged, undivided, unseparated manner, the difference between natures being never destroyed at all because of the union, but rather the characteristic of each nature being preserved and flowing together in a person and a hypostasis" [35]. Thus, by this hypostatic - apophatic union - is "guaranteed", as Father Dumitru Stăniloae says, "the maximal value of the human persons, but also their eternity" [36].

The final aim of the assuming of the human nature in Christ is Salvation, ascending and being seated as a man at the right hand of the Father - the lifting of man to the state of partner of God. "All the mystery of the oikonomy is found in the kenosis of God's Son" [37] says Saint Cyril of Alexandria. Christ renounces His own will, out of love, to accomplish the Father's will, being "obedient unto death, even to death on the Cross". The divine will in Christ, says Vladimir Lossky, was the common will of the Three: "the will of the Father spring of will, the will of the Son - obedience, the will of the Holy Spirit - accomplishment" 
[38]. "Because there is nothing that the Son can do and the Father cannot do" [39]. For this reason, Christ's work accomplished on earth is a work attributed to the Holy Trinity, from whom Christ as God's Son cannot get separated, having the same being and the same will as the Father and the Holy Spirit. "It is not the same to want and to want in a certain way" [40], says Saint Maximus the Confessor, showing by this that in Christ there is no possibility of activating and updating the human nature obligatorily and against its will, in an individualistic and selfish manner, according to personal and not common aims. The updating of the nature in Christ's hypostasis occurs willingly but also in agreement with the needs and powers of the nature. Christ, by assuming the human nature, does not exclude its human will claimed by the human nature, but its way of activation and actualization is realized by the Hypostasis of Christ, Which desires the divine things and does not breach in any way the natural ones. Christ actualized the human nature in His Unique Hypostasis according to the individual, but also the common good at the same time. He gave satisfaction both at the individual and at the general-cosmic level. Of His human nature, actualized (deified) in the fullest manner, benefit as well - as of a spring of life - the other human persons hypostatized individually in Christ. He is the Unifier of all since "the person, being a unity, involves and always refers positively to the other persons" [41]. Thus, Saint Maximus says: "Though Christ had His natural will as a man, He always wanted in essence what God naturally put in [His divine] nature, when He gave Him the existence by the creation." [42].

As one can observe, out of the above, the whole reality exists in order to personalize Him in a hypostasis. The whole reality is meant to become hypostatized nature, undergoing an endless enrichment. For this reason, the soul has been created by God with certain tendencies of organization of the matter in the body, actually each soul is meant for getting united with a body of its own, more than for remaining in a unity with the other souls. The union with God is realized in hypostasis and not according to the being. Christ is the One Who perfectly unites, in His special Hypostasis, God with man and with the whole world. This ascension of ours towards the unitary Hypostasis is realized only in grace with the voluntary support of the mind and of reason towards the increase of faith and of the virtues. Christ is the unique and the most comprehensive Person enhypostatizing [43] the whole species, nature, substance. Yet, this species is at the same time hypostatic, aware and free in an absolute manner - to the detriment of the common Hypostasis of the Logos. By this, Saint Maximus shows that this is not just about enhypostatizing, but this also involves a growth of the human nature in Christ by composition, so that the whole human nature hypostatized gains in Christ its own identity. Therefore, Christ is, by His Hypostasis, in which the two natures are united, a unifying bridge between God and the humanity. "The Same both One and two" [44], says Saint Maximus, Who unites in His Unique and special Hypostasis both parties, in an entirety, the entirety being the unity of the person, the parts being its composition. "Christ", says Saint Maximus, "is not just out of parts, but is also in parts and better said is these [parts]". In Christ, the person is made up of the two natures, which remain always distinct and unchanging, bearing in them the seal of the same hypostasis. Only in this way, says Saint Maximus, "His is the cross and the death and the tomb and the resurrection and the ascent to heaven" [45], because all the things that happen in His components are His, are lived by Him. This aspect is grasped by Vladimir Lossky when he says: "God's Son suffered, died on the cross, yet with what had the possibility to die and to suffer, namely His human nature. At the same time, we will be able to say that while being born as a baby in the manger of Bethlehem, being hanged on the cross or resting 
in the grave, He never ceased to rule - by His almightiness - over the created world, by virtue of His divinity, which undergoes no change at all" [46].

Consequently, from Christology, Saint Maximus the Confessor draws conclusions of spiritualization of man. Christ's Passion had the ontological meaning of lifting of the human nature from the weakness and death that follow sin, so that we, too, may have the possibility to free ourselves from these weaknesses. By His Embodiment, Christ gathered to Himself and in Himself the whole human nature. His Embodiment has, therefore, a redeeming sense: by the Embodiment, the human nature is lifted from sin and put in a close relation with us and at the same time with God. Consequently, we can say that the Embodiment, which involves the un-confounded union of the distinct natures in the eternal Hypostasis of the Logos, is the first act of our salvation.

\section{Conclusions: Christ - our salvation and deification}

Any Christian is called to discover his own nature in the personal communion with God and with the other fellows, in order to make it present by the perseverance in doing good and therefore in acquiring virtues, supported by reason. By creation, man has a natural power to maintain himself in this communion, a power represented by the relentless movement of the nature, incessantly tending towards action. A nature without power cannot exist, the power of the nature being manifested in action, because "what has no power, says Saint Maximus the Confessor, has no action, either" [47]. The action of the nature depends, therefore, on the power, on the power of the substance, and therefore there is a permanent natural tendency of the beings towards purifying and perfecting their earthly existence. Yet, we do not have everything by the action of nature, the action of the human nature is maintained as seizing, we can seize and at the same time we can acquire through it all that is given to us, and so there is an increase, depending on and according to what we receive. $\mathrm{He}$ who does what is good consolidates himself in life, namely in the eternity. For this reason, as Father Dumitru Stăniloae says, "man has, sown in his nature, the need and the capacity of communion with God, as the eye has, sown in its nature, the capacity to see the light, distinct from him", and by participation to this communion with the help of reason, man becomes the bearer of God's features, man appears as God, is deified. The deification is not the explicit work of our natural power, but is the work of God's action. Thus, the human work experiences, feels and lives the deification, but it is not the human work the one that produces this deification, but it is the result of the persistence of the human being, of its will and work in this union with God, by mutual circumcision [that property by which the Divine Persons, by reason of the identity of their natures, communicate with each other] up the total impression of the divine goods in the human being, which Saint Maximus the Confessor calls "the perichoretic action" by which man's eternal rest will keep forever the character of communion.

This resettlement and full revelation of the human nature was realized and is realized to the full in Jesus Christ, truly God and truly man, more truthfully said the man-God, "Who, although He was in the form of God, did not regard equality with God a thing to be grasped, but emptied Himself, taking on the form of a servant, being born in the likeness of man. And being found in appearance as a man, He humbled Himself, becoming obedient to the point of death, even death on a cross!" (Philippians 2:6-9). So much, says Saint Maximus, did God descend and make Himself a man, without sin, "that it seemed to the unbelievers that He is no God" [48]. His descent became the condition of our salvation. To the assimilation by God of the human nature must answer the assimilation by us of the divine nature. The human 
nature becomes in Jesus, the Hypostasis of the Word, a personalized nature, a nature impressed by the divine features, yet not as a necessary effect of it, but by the will of the Hypostasis of the Word, namely by the oikonomia of the Son, Who works both kinds of things, the divine and the human ones, according to their nature, through the participation of one to the other without a separation of them. We understand by this that "the same Hypostasis, of the Logos, is the hypostasis of the two natures" [49] as Saint John Damascene says, carrying out all the things that are human in a divine manner and all the things that are divine in a human manner, because "He, being rich, became poor for us, to make us rich by His poverty" (2 Corinthians 8:9), to make us gods, too, in the union with Him, by grace. In this sense, Leontius of Byzantium said: "the only remedy of our disease is the descent of the Son" [50]. In the hypostasis of the two natures, therefore, takes effect the humanization of the Logos and the deification of the human nature. The Self of the Son, says Father Dumitru Stăniloae, includes after the embodiment the human nature as well, making himself hypostasis for the body as well. [51] The Logos becomes a hypostasis of everyone by His embodiment, uniting in His Self both the divine nature and the human nature, and His Self does not penetrate in God as in someone foreign, because He Himself is infinite God, which makes the human nature assumed realize the return to God in a state of grace, in a familial state by the affiliation between it and the divine nature realized in the Hypostasis of the Embodied Son.

* This article was presented to the doctoral courses bachelors of Theology, organized by the Faculty of Orthodox Theology, "Bucharest University", Romania, under the guidance of Rev. Prof. Dr. Vasile Răducă, which gave the accept to be published.

\section{REFERENCES}

[1]. Fr. Prof Dr. Dumitru Stăniloae, Teologia Dogmatică Ortodoxă (Orthodox Dogmatic Theology), vol. 2, second edition, Ed. IBMBOR, București 1997, p. 38

[2]. Ibid., p. 39

[3]. Ibid.

[4]. Sfântul Maxim Mărturisitorul (Saint Maximus the Confessor), Liber asceticus, P.G. 90 col. 912A; translated in Romanian by Fr. Prof. Dumitru Stăniloae in Filocalia (Philocalia), vol. II, Ed. Humanitas, București 2009, p. 23

[5]. Fr. Prof. Dr. Dumitru Stăniloae, op.cit., pp. 31-32

[6]. Nicolae Cabasila, De vita in Christo, P.G. 150, col 537D; translated in Romanian by Fr. Prof. Teodor Bodogae, Ed. IBMBOR, București, 2009, p. 27

[7]. The impossibility to separate in Christ the two natures permitted to the Holy Fathers of the Fifth Ecumenical Synod to also use the expression "out of two natures", yet on condition that this expression ought not to be understood as a confounding of the two natures. The intention of the use of this expression was initially to attract to the accurate faith the old Oriental Churches, which had a real inclination towards embracing the dangerous heresy of Eutychius, namely Monophysitism.

[8]. Sfântul Maxim Mărturisitorul (Saint Maximus the Confessor), Quaestiones ad Thallassium, P.G. 90, col. 274B-276A; translated in Romanian by Fr. Prof. Dumitru Stăniloae, in Filocalia (Philocalia), vol. III (electronic edition), Ed. Apologeticum 2005, p.48-49

[9]. Leonţiu de Bizanţ (Leontius of Byzantium), Adv. Nestorianos, libr. VI, P.G. 86, col.1 197C apud Fr. Prof Dr. Dumitru Stăniloae, Teologia Dogmatică ..., Ed. cit., p. 36 
[10]. Sf Ioan Damaschin (St. John Damascene), Contra Jacobitas, P.G. 94 col. 1464 A apud Vladimir Lossky, Teologia Mistică a Bisericii de Răsărit (The Mystical Theology of the Eastern Church), translated by Fr. Prof. Dr. Vasile Răducă, Ed. Anastasia, București 1993, p.168

[11]. Fr. Prof Dr. Dumitru Stăniloae, op.cit., p. 38

[12]. Panayotis Nellas, Omul - animal îndumnezeit (Zoon theoumenon), translated by Deac. Ioan I. Ică jr., Ed. Deisis, Sibiu 1994, p. 113

[13]. Vladimir Lossky, Teologia Mistică a Bisericii de Răsărit (The Mystical Theology of the Eastern Church), translated by Fr. Prof. Dr. Vasile Răducă, Ed. Anastasia, București 1993, p 180

[14]. Sfântul Grigorie de Nazianz (St. Gregory of Nazianzus), In sanctum Pascha, P.G. 36, col. 653 AB apud Vladimir Lossky, Teologia Mistică....., op. cit., p. 181

[15]. Idem, Epistole (Epistles), P.G. 37, col. 181 apud Vladimir Lossky, Teologia Mistică..., op.cit., p.183

[16]. Vladimir Lossky, op.cit, p.182

[17]. Origen, De principiis, P.G. 11, col. 129C apud Vladimir Lossky, Vederea lui Dumnezeu (The Vision of God), translated by Prof. Dr. Remus Rus, Ed. IBMBOR, București 1995, p. 50

[18]. Sfântul Maxim Mărturisitorul (Saint Maximus the Confessor), Epistolae, P.G. 91, col. 397A; translated in Romanian by Fr. Prof. Dumitru Stăniloae, in PSB 81, Ed. IBMBOR, București 1990 , p. 34

[19]. Idem, Ambigua, P.G. 91, col. 1036C; translated in Romanian by Fr. Prof. Dumitru Stăniloae, in PSB 80, Ed. IBMBOR, București 1983, p. 49

[20]. Idem, Epistolae, P.G. 91, col. 397D; translated in Romanian, PSB 81, op.cit., p. 34

[21]. Vladimir Lossky, Teologia Mistică..., op. cit., p. 166

[22]. Sfântul Maxim Mărturisitorul (Saint Maximus the Confessor), Capitum theologicorum et oeconomicorum, I, 66, P.G 90, col 1108B; in Filocalia (Philocalia), vol. II, op. cit., pp. 138-139

[23]. Vladimir Lossky, op.cit., p. 166

[24]. Sfântul Maxim Mărturisitorul (Saint Maximus the Confessor), Ambigua , P.G. 91 col. 1308; translated in Romanian, PSB 80, op. cit., p. 270

[25]. Ibid., P.G., col. 1288B , translated in Romanian, PSB 80, op. cit.,p. 246

[26]. Vladimir Lossky, Vederea lui Dumnezeu ..., op.cit., p. 68

[27]. Fr. Prof Dr. Dumitru Stăniloae, op.cit., p. 35

[28]. Sfântul Maxim Mărturisitorul (Saint Maximus the Confessor), Epistolae, P.G. 91, col. 397D; translated in Romanian, PSB 81, op. cit., p. 34

[29]. Ibid., P.G. 91, col. 410A, 412BC; translated in Romanian, PSB 81, op. cit., pp. 112-114

[30]. Vladimir Lossky, Teologia Mistică...., op. cit., p. 172

[31]. Sfântul Maxim Mărturisitorul (Saint Maximus the Confessor), Disputa cu Pirhus (The Dispute with Pyrrhus), P.G. 91, col. 337C- 340A; translated in Romanian, PSB 81, op. cit., pp.336-341

[32]. Sfântul Ioan Damaschin (Saint John Damascene), De fide ortodoxa P.G. 94, col 1013B apud Vladimir Lossky, Teologia Mistică....., op. cit., p.224

[33]. Sfântul Maxim Mărturisitorul (Saint Maximus the Confessor), Epistolae, P.G. 91, col. 604 BC; translated in Romanian, PSB 81, op.cit., p. 160

[34]. Ibid., P.G. 91, col. 420AB; translated in Romanian, PSB 81, op. cit., p. 117

[35]. Fr. Prof Dr. Dumitru Stăniloae, op.cit., p. 25

[36]. Ibid., p. 27

[37]. Sfântul Chiril al Alexandriei (Saint Cyril of Alexandria), Quod unus sit Christus, P.G. 75, 1308-1332 apud Vladimir Lossky, op. cit., p. 173

[38]. Vladimir Lossky, op.cit., p. 173

[39]. Sfântul Chiril al Alexandriei (Saint Cyril of Alexandria), In Johanem, P.G. 73 col.361D apud. Vladimir Lossky, op. cit., p. 176

[40]. Sfântul Maxim Mărturisitorul (Saint Maximus the Confessor), Disputa cu Pirhus (The Dispute with Pyrrhus), P.G. 91, 292 D; translated in Romanian, PSB 81, op. cit., p.321

[41]. Fr. Prof. Dr. Dumitru Stăniloae, op.cit., p. 30 
[42]. Sfântul Maxim Mărturisitorul (Saint Maximus the Confessor), Opuscula theologica et polemica, PG 91, col. 77; translated in Romanian, PSB 81, op. cit., p. 198

[43]. "The enhypostasis, says Saint Maximus the Confessor, is what does not subsist at all by itself, but is seen in others as a species in the individuals under it, or what is composed with something else, different according to the being [ontologcally], to give birth to someone", see Epistolae P.G. 91, col. 558D; translated in Romanian, PSB 81, ed.cit., p. 131

[44]. Ibid., P.G. 91, col. 562A; translated in Romanian, PSB 81, op. cit., p 134

[45]. Ibid., P.G. 91, col. 574BD; translated in Romanian, PSB 81, op. cit., p. 141-142

[46]. Vladimir Lossky, op. cit., p. 173

[47]. Sfântul Maxim Mărturisitorul (Saint Maximus the Confessor), Opuscula theologica et polemica, PG. 91, col. 24C; translated in Romanian, PSB 81, op. cit., p. 180

[48]. Fr. Prof. Dr. Dumitru Staniloae, op.cit., p. 41

[49]. Sfântul Ioan Damaschin (Saint John Damascene), Dogmatica (Dogmatics), translated by Dumitru Fecioru, Ed. Editura Librăriei Teologice, Bucureşti, 1938, p. 121

[50]. Leonţiu de Bizanţ (Leontius of Byzantium), Adver. Nestorianos, PG. 86, 1, col.1295; apud Fr. Prof. Dr.Dumitru Staniloae, op.cit., p. 34

[51]. Fr. Prof. Dr. Dumitru Staniloae, op.cit., p. 43

Prophets. Eds., James Luther Mays \& Paul J. Achtemeier. Fortress Press, U.S.A, 1987. 